\title{
Protocolo de recogida de muestras para cultivo del dializado y del agua tratada. Metodología y resultados
}

\author{
Beatriz Durana Tonder* \\ María del Carmen Prado Meis* \\ Vicente Domínguez Hernández* * \\ Miguel Rosales Rodríguez** \\ Cándido Díaz Rodríguez*
}

\author{
*Servicio de Nefrología. Unidad de Hemodiálisis \\ F.P.H. Virxe da Xunqueira. Cee (La Coruña) \\ **Servicio de Medicina Preventiva \\ Complejo Hospitalario Juan Canalejo \\ La Coruña
}

\section{RESUMEN}

El objetivo del estudio microbiológico del dializado y del agua tratada es prevenir las reacciones pirógenas y bacteriemias en los pacientes sometidos a diálisis. La contaminación de las muestras por una deficiente manipulación y/o defectos en el procedimiento se traducen en una situación de alarma. En los controles previos a la puesta en funcionamiento de nuestra unidad, se detectó que 3 cultivos de agua tratada, de 5 monitores eran positivos. Ante la posibilidad de que los cultivos fueran positivos por una manipulación inadecuada, se decidió establecer un protocolo para la recogida de muestras en el que se extremaran las medidas de asepsia. Tras la aplicación de dicho protocolo los resultados han sido negativos en todas las ocasiones.

$\begin{array}{ll}\text { PALABRAS CLAVE: } & \text { VIGILANCIA MICROBIOLÓGICA } \\ & \text { DIALIZADO } \\ & \text { AGUA TRATADA } \\ & \text { CONTAMINACIÓN } \\ & \text { PROTOCOLO }\end{array}$

Correspondencia:

Beatriz Durana Tonder

Servicio de Nefrología. Unidad de Hemodiálisis

F.P.H. Virxe da Xunqueira

Paseo Marítimo s/n

Cee 15270 (La Coruña)

\section{A PROTOCOL FOR THE COLLECTION OF SAM- PLES FOR THE CULTIVATION OF DIALYSIS LIQ- UID AND OF TREATED WATER. METHODOLOGY AND RESULTS}

\section{SUMMARY}

The objective of this microbiological study of dialysis liquid and treated water is to prevent pirogenic and bacteriemia in patients undergoing dialysis. The contamination of samples because of poor handling and / or faulty procedures is becoming an alarming situation. In preliminary checks at the working station of our unit, 3 of the 5 cultures of treated water were found to be positive. Facing the possibililty that the cultures were positive as a result of poor handling, it was decided to establish a protocol for the collection of samples in which every effort was made to maintain aseptic conditions. Through the application of this protocol the results have been negative on each occasion.

KEY WORDS: MICROBIOLOGICAL VIGILANCE DIALYSIS LIQUID TREATED WATER CONTAMINATION PROTOCOL 


\section{INTRODUCCIÓN}

Según establece la norma UNE 111-301-90 del Comité Técnico AENOR, el contaje total microbiano debe ser menor o igual a $200 \mathrm{UFC} / \mathrm{ml}$ en el agua de diálisis y menor o igual a $2000 \mathrm{UFC} / \mathrm{ml}$ en el dializado, cuando se realizan determinadas técnicas, como la hemodiafiltración "en línea", parece lógico aumentar estos márgenes de seguridad. Se recomienda la recogida de muestras para cultivo tanto del agua como del dializado al menos una vez al mes $\mathrm{y}$, siempre ante cualquier reacción a pirógenos o bacteriemias inexplicadas que se presenten en los pacientes de la unidad de hemodiálisis. Las muestras para control bacteriológico deben ser recogidas cuidadosamente y procesadas antes de $60 \mathrm{mi}-$ nutos, o bien, conservadas a $5^{\circ} \mathrm{C}$ un máximo de 24 horas. Es conveniente usar medios de cultivo con sal y pobres en nutrientes, a temperatura entre 35 y $37^{\circ} \mathrm{C}$. En los controles previos a la puesta en funcionamiento de nuestra unidad, se detectó que 3 cultivos de agua tratada procedentes de 5 monitores eran positivos, esto se tradujo en una situación de alarma que obligó a retrasar la apertura de la unidad una semana.

Esta situación nos obligó a un replanteamiento paso a paso de todo el procedimiento, y elaboramos un protocolo en el que quedaran meticulosamente reflejados todos los pasos a seguir antes de recoger las segundas muestras, con el fin de evitar su contaminación.

Presentamos el protocolo que seguimos en nuestra Unidad para la recogida de muestras de agua tratada y del dializado, y los resultados obtenidos antes y después de la su aplicación.

\section{MATERIAL Y MÉTODOS}

\section{PROTOCOLO DE RECOGIDA DE MUESTRAS Material necesario:}

- Recipientes estériles de $100 \mathrm{ml}$. con tapa.

- Parafilm.

- Cubeta con hipoclorito sódico al 2\% (Amuchina $\left.{ }^{\circledR}\right)$.

- Cubeta con agua tratada.

- Cubeta vacía para drenaje del dializado.

- Guantes de látex.

\section{Condiciones para la recogida:}

- El monitor no debe estar conectado al paciente.

- El personal que vaya a recoger las muestras se calzará guantes de látex.

- Desconectar del monitor la línea de dializado (tapón azul) y sumergirla en la cubeta con hipoclorito sódico al 2\% (Amuchina ${ }^{\circledR}$ ) durante 30 minutos.
- Enjuagar la línea 3 veces sucesivas en la cubeta con agua tratada cambiando el agua cada vez.

- Volver a conectar la línea al monitor.

\section{Procedimiento}

- La muestra para el cultivo debe obtenerse mientras el aparato (DRAY WILOCK) esta todavía siendo enjuagado con agua, inmediatamente después de enjuagar todo el desinfectante residual del sistema.

- Pulsar el interruptor de derivación manual para detener el flujo en las líneas de dializado.

- Desconectar del monitor la línea de dializado (tapón azul).

- Sin tocar la abertura del conector del dializador o la zona circundante, sujetar el conector sobre la cubeta vacía, de modo que el chorro de líquido fluya directamente de la parte inferior del conector.

- Pulsar el interruptor de derivación manual (by-pass) para iniciar el flujo a través de la línea del dializado.

- Dejar que el sistema drene durante 2 minutos.

- Colocar el recipiente de recogida de muestras estéril bajo el chorro y recoger asépticamente una muestra de líquido de $100 \mathrm{ml}$.

- Cerrar asépticamente el recipiente de la muestra.

- Sellar el recipiente con parafilm.

- Las muestras deben ser transportadas en frío hasta el Laboratorio de Medicina Preventiva o Microbiología.

- Pulsar el interruptor de derivación manual (by-pass) para interrumpir el flujo en las líneas de dializado.

- Conectar la línea de dializado al monitor.

Para la recogida de muestras de agua tratada se deja que cualquier toma de agua drene durante dos minutos, antes de recoger la muestra de manera aséptica.

\section{RESULTADOS}

Como podemos apreciar en la tabla I, los cultivos de las primeras muestras de agua tratada procedente de la línea de dializado de 3 de los 5 monitores (monitores 0,1 y 3) resultaron positivos, con crecimiento de flora mixta de bacilos Gram positivos y Gram negativos en el monitor $\mathrm{n}^{\circ} 0$, de Proteus mirabilis en el monitor $\mathrm{n}^{\circ}$ 1 y de bacilos Gram negativos en el $n^{\circ} 3$. Tras la aplicación del protocolo, los resultados han sido negativos en todas las ocasiones. Los cultivos del agua tratada procedentes de la instalación general fueron negativos en todo momento. 


\section{DISCUSIÓN}

La vigilancia microbiológica en las Unidades de Hemodiálisis es fundamental para evitar reacciones a pirógenos debido a la contaminación bacteriana de los líquidos de diálisis.

En nuestro caso, los resultados positivos de las primeras muestras se tradujeron en una situación de alarma y en un retraso en la apertura de la Unidad. Tras la aplicación de un protocolo de recogida de muestras los resultados de los segundos cultivos y de los posteriores, han sido negativos en todo momento, lo que confirma un defecto en la manipulación de las muestras, como causa de la positividad de los primeros cultivos.

El paso más conflictivo, y por lo tanto donde más precaución debemos tener, es en la recogida de muestras de los monitores, ya que los conectores del dializado están contaminados debido a la manipulación habitual durante el proceso de diálisis.

La dificultad para la recogida de muestras del agua tratada de la instalación general es menor; prueba de esta menor dificultad es que en nuestro caso todos los cultivos del agua, incluidos los primeros, fueron negativos.

\section{CONCLUSIONES}

1. Un defecto en la manipulación o en el procedimiento de recogida de muestras es probable que pueda ser una de las causas de cultivos positivos.
2. El desarrollo y aplicación de un protocolo donde se reflejen de manera meticulosa tanto los diferentes pasos del proceso, incidiendo en aquellos en los que existe más riesgo de contaminación, como las medidas de asepsia que se deben emplear, se traduce en una disminución del numero de cultivos positivos.

3. Una adecuada aplicación del protocolo evitará situaciones de alarma y aumentará la efectividad de la propia Unidad de Hemodiálisis.

\section{BIBLIOGRAFÍA}

1. Comité Técnico AENOR: Norma UNE 111-301-90. Características del agua utilizada en hemodiálisis. Nefrología 1991;11: 7-8.

2. Torregrosa I, Pérez A, Giménez M. Tratamiento del agua para hemodiálisis. Nefrología 1998;18:14-21.

3. Arduino MJ, Bland LA, Aguero SM, Favero MS. Effects of incubation time and temperature on microbiologic sampling procedures for haemodialysis fluids. J Clin Microbiol 1991; 29:1462-1465.

4. Klein E, Pass T, Harding GB, Wright R, Milion C. Microbial and endotoxin contamination in water and dialysate in the central United States. Artif Organs 1990; 14: 85-94.

\begin{tabular}{|c|c|c|c|c|c|c|}
\hline Fecha & Instal. general & Monitor 0 & Monitor 1 & Monitor 2 & Monitor 3 & Monitor 4 \\
\hline $14 / 11 / 01$ & Negativo & $\begin{array}{l}\text { Bacilo G+ } \\
\text { Bacilo G- }\end{array}$ & P. mirabilis & Negativo & Bacilo G+ & \\
\hline $19 / 11 / 01$ & Negativo & Negativo & Negativo & Negativo & Negativo & Negativo \\
\hline $21 / 12 / 01$ & Negativo & Negativo & Negativo & Negativo & Negativo & - \\
\hline 06/02/02 & Negativo & - & Negativo & Negativo & - & - \\
\hline $27 / 02 / 02$ & Negativo & Negativo & - & - & - & Negativo \\
\hline $20 / 03 / 02$ & Negativo & - & - & Negativo & Negativo & - \\
\hline $24 / 04 / 02$ & Negativo & Negativo & Negativo & - & - & - \\
\hline $22 / 05 / 02$ & Negativo & - & - & - & Negativo & Negativo \\
\hline $19 / 06 / 02$ & Negativo & - & Negativo & - & - & Negativo \\
\hline $17 / 07 / 02$ & Negativo & Negativo & - & Negativo & - & - \\
\hline $28 / 08 / 02$ & Negativo & - & - & - & Negativo & Negativo \\
\hline
\end{tabular}

Tabla I: Resultados del análisis microbiológico del agua tratada de la instalación general y de la salida de los monitores. 